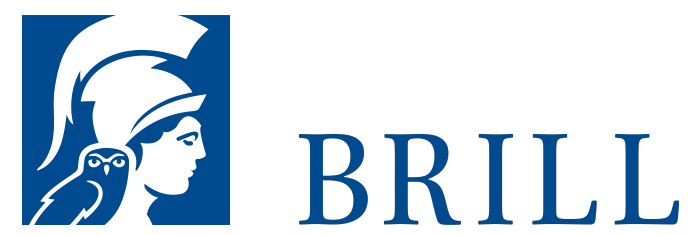

\title{
Kafkas bewegte Körper
}

Die Tagebücher und Briefe als Laboratorien von Bewegung

Author: Elisabeth Lack

Franz Kafkas Tagebücher und Briefe sind ein Fundus für die literarische Darstellung expressiver Körper. 'Kafkas bewegte Körper - Die Tagebücher und Briefe als Laboratorien von Bewegung' ist die erste Auseinandersetzung mit den literarischen Möglichkeiten und Verfahren des Motion Capturing in Kafkas Schreiben. Elisabeth Lack arbeitet Kafkas spezifische >somatologische< Poetologie heraus, die sich aus dessen Arbeit an der Metapher ableitet und weist auf die Nähe seiner bewegten Körper zur Körperdarstellung in den neuen Medien, z.B. in den gezoomten oder im Tempo verzerrten Bewegungen in den Fotografien Muybridges hin.

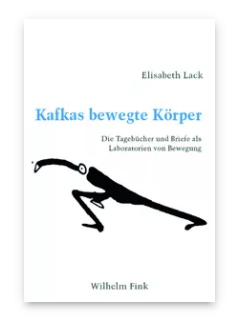

Pages: 254

Seiten

Language:

German

Subjects:

General,

Literature and

Cultural Studies

Publisher: Brill |

Fink

E-Book (PDF)

Released online:

o1 Oct 2019

ISBN: $978-3-$

8467-4856-5

List price

USD $\$ 54.00$

Paperback

Publication date:

28 Oct 2009

ISBN: 978-3-

7705-4856-9

List price

USD \$54.00 
For more information see brill.com

Order information: Order online at brill.com +44330 333 0049 | customerservices@brill.com Submission information: brill.com/authors

Titles published by Brill | Fink, Brill | mentis or Brill | Schöningh: +49(o)715413279216| brill@brocom.de 